\title{
ペトリネットを利用した 造船工場シミュレータの構築
}

\author{
正員 青 山 和 浩* 正員 野 本 敏 治* \\ 正員 渡 辺 健太郎**
}

Development of Shipyard Simulation System based on Petri Net

by Kazuhiro Aoyama, Member
Kentaro Watanabe, Member

Toshiharu Nomoto, Member

\begin{abstract}
Summary
It is needless to say that much information on process planning and scheduling is very important for production activities. There are various restrictions in the factory. The most efficient production schedule must be planned in consideration of those restrictions. However, information handled by production scheduling is huge and it is very difficult to plan the best schedule. Therefore, skill is needed for production scheduling.

In this research, authors use the Petri Net that is suitable for modeling the parallel, asynchronous system, and the nondetermination event to support production scheduling with the computer simulator of a shipyard. We aimed to implement the factory simulation system of the shipbuilding. We have already implemented the production scheduling support system in the shipyard that is partially of our research in CIM for shipbuilding.

In order to use this result of our research more, we implement the system that can evaluate the effectiveness of generated production schedule by the factory simulator. Time is freely controlled in the computer and we implement the shipyard simulation system that can simulate the process of the production activity in a shipyard. This paper shows the effectiveness of the use the factory simulator.
\end{abstract}

\section{1. は じめに}

製造業では, 生産活動における膨大な情報の管理や処理 の効率化などの諸問題に対して, 計算機等を利用した生産 システムを構築している。1970 年代に入って体系化が始め られた生産システムは，「設計，管理などで代表される“情 報の流れ”と製造で代表される“物の流れ”とを有機的に 結合する」ことを目的とする学問体系であり, 生産活動の 全過程を情報処理技術によってシステムとして捉える考え 方である11。

設計においては, 製品情報の電子情報化を目的に様々な CAD (Computer Aided Design) などの設計システムが数

* 東京大学大学院工学系研究科

** 石川島播磨重工業株式会社（研究当時：東京大学大 学院工学系研究科)

原稿受理 平成 9 年 7 月 10 日

秋季講演会に拈いて講演 平成 9 年 11 月 14,15 日
多く開発・導入されるだけでなく, CAE (Computer Aided Engineering）が積極的に導入されている。CAEの導入に より，設計者は製品の評価・検討を自由にでき，最適な製 品を設計することが可能な環境が整備されつつある。計算 機の利用は, 生産計画においても重要であり, 生産スケジ ユールを, 計算機を利用して立案できる様々な生産計画支 援システムが構築され利用されている213)。それらのシステ ムは有用であるが, 生産のスケジュール情報を効率的に生 成することに限定されていると認識できる。つまり, 生産 計画支援システムは，ガントチャートによる日程表示や， 作業の山積みなどの情報を計画者に提示することはできる が, 生成されたスケジュールの実現性や最適性などの評価 は, 熟練計画者の経験や勘などに依存していると言える。 したがって, 処理すべき計画の情報が膨大になれば, 計画 の評価は困難になることは避けられない。このことから， 設計における計算機支援と比較すると, 生産計画において は計画者の評価を支援できるようなシステムが十分に完備 されていないものと考えられ, そのようなシステムを構築 
する必要がある。

本研究では, 多品種少量生産型の典型と言われる造船に おいて, 工場を効率よく稼働させるために必要不可欠な生 産スケジュールの立案を支援するシステムの構築を検討し た。具体的には，生産資源の様々な制約を考慮し，立案さ れた生産スケジュールの実現性などを評価したり，様々な スケジュール情報を計画者に提示しながら，最適な計画を 立案支援する工場シミュレータを構築することを目的とす る。これまでの著者らの研究が製品モデルを中核にする研 究であったことに対して，本研究は，工場シミュレータの 構築という立場から，計算機内における工場モデルの明確 化を目的とする。以下に, 本研究の目的を整理する。

・造船工場での生産活動を整理し, 生産活動のシミュレー ションを行なうために必要な情報を整理する。

・工場における生産活動の機能を，ペトリネットを用いて 表現し, 生産活動のシミュレーションが実行可能な工場 シミュレータを構築する。

・シミュレーションによって得られる情報を整理し，スケ ジューリングにおける工場シミュレータの利用の有効性 を検討する。

\section{2. 工場と生産活動}

工場シミュレータの構築によって, 工場における生産活 動のシミュレーションの実現を目的としている。そのため に本章では, 生産活動の特徴を整理し, 造船工場の役割を 抽出することによって，工場シミュレータの中核となる工 場モデルに必要な情報と機能を明確にする。

\section{1 生産活動の特徵}

多品種少量生産型の工場は, 一般にジョブショップと呼 ばれる。ジョブショップでは, 固定化された生産ラインの 概念はなく，中間製品が生産設備をどの様に通過するかと いった生産ルートは, 個々の製品に対して決められること が特徵である。多品種少量生産型の典型である造船工場に

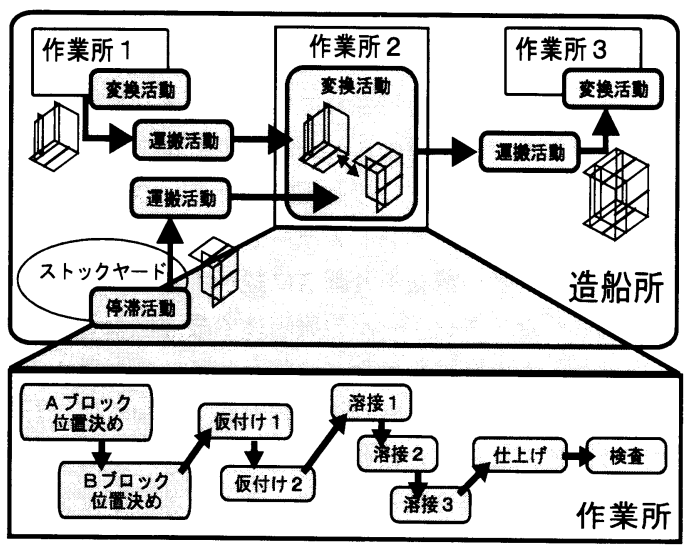

Fig. 1 Flow of Products and Flow of Jobs
おける生産活動を，「“物の流れ”の視点」と「“作業の流れ” の視点」の二つの視点で捉え，その特徵を整理する (Fig. 1)。

\section{（1）“物の流れ”の視点}

造船工場には, 切断・加工工程, 小組工程, 大組工程, 外業工程などの目的別に整理された様々な工程が存在し, 生産活動はそれらの工程の組合せによって実現化される。 それらの工程では，生産対象である素材や中間製品を形態 的に変化させる活動が実施される。本研究ではその活動を 変換活動と呼ぶ。この変換活動が行われる複数の工程を円 滑に連結するために，生産対象を運搬したり，ストックヤ ードに保管するなどの活動が実施される。本研究ではそれ らの活動を, 運搬活動および停滞活動と呼ぶ。このように, 生産活動を変換活動, 運搬活動, 停滞活動の連続した活動 の組み合わせとして捉えた場合，個々の活動の対象は素材 や中間製品といった生産対象そのものであり, 生産活動に おける工程間の生産対象の流れを認識することができる。 本研究では，この流れを“物の流れ”と定義する。

(2) “作業の流れ”の視点

上記 ( 1 ) で列挙した活動には様々な具体的な実施作業が 存在する。例えば変換活動が実施される工程には, 溶接作 業などの作業が存在する。また，同様に，運搬活動や停滞 活動においても各々の活動を実施するための作業が存在す る。（1）では，生産活動における工程間の生産対象の流れ を“物の流れ”として捉えたが, これに対して, 生産活動 に扔ける作業の媻がり（流れ）を“作業の流れ”として捉 えることができる。

\section{2 生産資源が生産活動に及ぼす制約}

生産活動を実施する主体は生産資源と呼ばれる。どの様 な仕事に対しても，この生産資源が，同時にかつ無制限に 処理可能であるならば，事前の生産計画の必要性は減少す る。しかし現実には, 生産資源固有の生産能力に起因する 制約や，生産資源のスケジューリング（作業の実施日程） による時間的な制約などが存在する。したがって，実際の 生産活動を実施する前に，可能な限り詳細な生産計画が必 要となる。本研究では, 前者の制約を「能力因子による制 約」, 後者を「時間因子による制約」と呼び，各々の制約に 関して以下のように整理する。

（1）能力因子による制約

ある作業をある生産資源に割り当てる際には，その作業 がその生産資源によって実施可能であるか不可能であるか を判断する必要がある。この時に考慮される制約は, 後述 する工程計画で検討される。例えばこの制約は，建屋の大 きさ(高さ, 幅など), 組立定盤の有効面積, クレーンの吊 り許容能力などの生産資源の物理的な制約によって規定さ れる制約である。本研究では，このような作業が可能であ るか不可能であるかの判断基準に関連する制約を「能力因 子による制約」として定義し，物や作業の流れを実現する 
ための絶対条件となる制約として考える。

ところで, 溶接機の溶接効率や作業者の作業効率なども 能力因子による制約に関連するが, 本研究では, それらの 生産効率に関係するような因子は, 後述する「時間因子に よる制約」に影響を及ぼす因子と考え，「能力因子による制 約」には含まれないものと考える。

（2）時間因子による制約

「一台の溶接機は, 複数の溶接作業を同時に実施できな い」といったように, ある作業の実施が, 他の作業の実施 を時間的に制約する場合がある。本研究ではこのような制 約を「時間因子による制約」と定義する。工場内に存在す る複数の生産資源のスケジュールは個々に独立するもので はなく, 個々のスケジュールは複雑に時間軸上で関係づけ られており, 時間的な相互関係が存在している。したがっ て, ある生産資源のスケジュールの変更は, 関連する生産 資源のスケジュールに影響を及ぼし，全体的なスケジュー ル変更を発生させる可能性がある。この時間因子の制約は, “物の流れ”や“作業の流れ”の効率に影響を及ぼす制約で ある。物や作業の流れがスムースかどうかは生産資源の生 産効率やスケジューリングなどの詳細な検討が重要とな り, 全体的な評価が重要となることが特徴である。

\section{3 生産計画の特徵}

生産計画は, 作業の内容とその日程を立案するために行 われ, 組立順序や作業順序を立案する工程計画と, 日程を 立案する日程計画とに大別される (Fig. 2)。

\section{(1) 工程計画}

工程計画は, 生産資源の能力を考虑しながら, 実施可能 な生産活動のシナリオを決定する計画である。工程計画に は大別して，工程の䌘がりである“物の流れ”を中心に全 体の生産活動を計画する工程設計と, 各工程で実施すべき 作業を抽出し, “作業の流れ”を中心に生産活動のシナリオ
を決定する作業設計の二つの設計から構成される。工程計 画では, 主に生産資源の「能力因子による制約」を考慮し て作業とその繫がりを決定する。また, 工程計画は個々の 製品に対して計画することが特徵であり, 製品を造るため の作業内容および作業順序を計画し, 関連し合う作業間の (前後) 関係を決定する。

(2) 日程計画

日程計画では, 工程計画によって得られる生産活動のシ ナリオを基に, 時間・場所・設備の使用効率を考慮に入れ ながら生産活動の日程情報が生成される。工程計画では 個々の製品を対象とするが, 日程計画では同時に複数製品 の生産スケジュールを考慮しなければならず, 工場単位の 計画を作成することが特徵である。つまり, 工程計画では 特に検討されることはない「ある組立定盤において A 船の ブロックと B 船のブロックとでは, どちらのブロックを優 先的に組み立てた方が有効であるか」などを検討する。つ まり, 独立関係になってしまう複数の組立作業の前後関係 を検討する必要がある ${ }^{3)}$ 。生産資源の視点から日程計画の 特徵を捉えると, 日程計画は生産資源が処理する作業の順 序および日程を決定する計画であると理解できる。

計画を決定する際には, 時間軸上での評価, つまり生産 資源の「時間因子による制約」を考慮する必要があり, 膨 大な量の作業を対象に検討しなければならないため, 計画 自体が煩雑になってしまう。そのために計算機を利用して, 日程計画情報の生成を支援することは重要である。

\section{4 生産計画における問題点}

造船における生産計画は, 大日程, 中日程, 小曰程の順 で立案される。特に中日程, 小日程においては建造に要す る組立手順, 作業内容及び作業順序などが検討され, 所有 する生産資源を可能な限り有効に利用することができる計 画情報を生成している。生成される日程はガントチャート

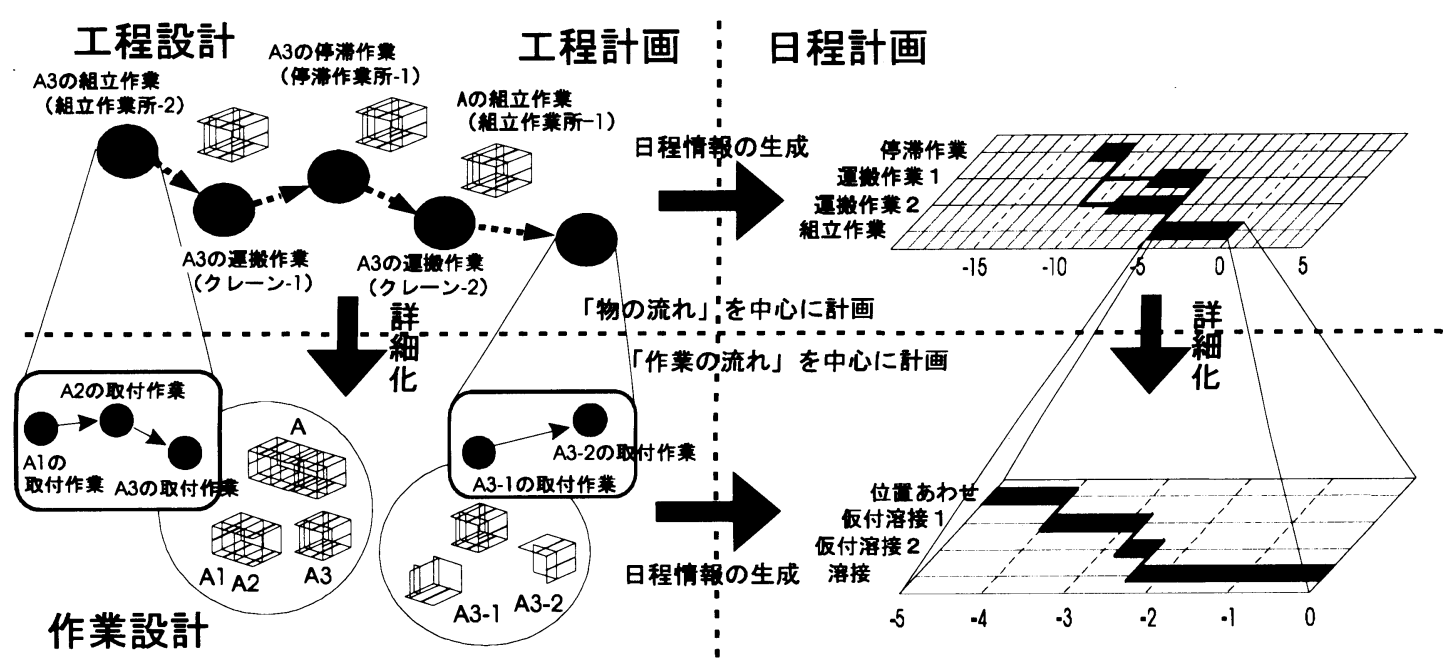

Fig. 2 Process Planning and Scheduling 
によって表示され，日程の無理や無駄などのチェックはガ ントチャート上で行われる。また，クレーンや定盤のよう な汎用性が高く使用頻度が高い生産資源，および板継ぎ溶 接装置などの大型専用装置のようなスケジュール管理が重 要となる生産資源を対象に，作業負荷などを集計しグラフ として表示する「山積み」などが示される。計画者は, こ のグラフから得られる情報を基に, 立案された計画の問題 点を見つけ, 処理される作業量の全体的なバランスを考え, 効率の良い計画に修正する。これは「山崩し・山ならし」 と呼ばれるものである。以上の計画は, ガントチャートを 基盤とした生産資源の「時間因子による制約」の評価を実 施するものと理解できる。

しかし，既に述べているように，計画が大規模になれば なるほど生産資源の「時間因子による制約」を考慮するた めに必要な時間および作業量は増大し, 生産計画者の直接 的な負担の増加は避けられなく, 最適な計画の立案は困難 なものとなってしまう。したがって, 以上のような情報処 理は, 計算機を利用することが望まれている範囲であり, 特に生産資源の「時間因子による制約」を容易に考慮する ことができるようになれば，最適な生産計画を立案する可 能性が拡がるものと考えられる。

\section{5 工場モデルの要件}

造船工場は，個々の製品に対して生産ルートが決められ るジョブショップであることは既に述べた。このジョブシ ヨップは，任意の種類の製品を扱うことができる利点があ る反面, 生産ルートの取り方によっては多くの生産設備に 長時間の空きが生じ，生産効率が悪くなる可能性がある。

生産効率をより良くするために, “物の流れ”や“作業の 流れ”を如何に効率的に実施するかを検討する必要がある。 “物の流れ”と“作業の流れ”を実現するためには, 先ず「能 力因子による制約」に反していないかどうかが把握できな ければいけない。つまり, 指定された生産資源で行われる 一連の作業ひとつひとつが可能か否かを判断できる必要が ある。また，「時間因子による制約」にっって生じてしまう 「物や作業の停滞状態」を容易に把握できることは重要であ る。

以上のことを支援するシステムを構築するためには, 工 程内の “作業の流れ”と工程間の “物の流れ”に関する情 報を整理し, 製品が工場内を流れること, 作業者が複数の 定盤を移動し機器を使用して作業を実施することなどをモ デル化することが必要である。

\section{3. ペトリネットによる工場の表現}

\section{1 ペトリネットの概要}

生産活動のシステムは離散事象システムであり, 特に, ジョブショップにおける生産活動は各生産設備において並 列かつ非同期であることが特徵である。そのような離散事 象システムを表現するツールとしてペトリネットが提案さ
れている45)。ペトリネットは工学的な環境における並列性 や非同期性を表現するのに適当なツールであると言われて いる。ペトリネットの適用例としては, マルチプロセッサ 分散処理システムのアーキテクチャや分散データベースシ ステムのモデル化などもある。

ペトリネットは, 以下に示す 4 つの要素によって表現さ れるモデルである (Fig. 3)。

・事象を表すトランジション

・条件を表すプレース

・トランジションとプレースを関係付けるアーク

・モデルの中を流れるトークン

ペトリネットを利用することで,「条件が揃うことによっ てある事象が生起し，その結果，新たな条件が生じる」と いった活動を「入力プレースにトークンが揃ったときトラ ンジションが発火し, 出力プレースにトークンが流れる」 というように表現することが可能である。この様な特徵か ら，ペトリネットは生産活動における“物の流れ”や”“作 業の流れ””をシミュレーションする上で有効なモデルであ ると理解できる ${ }^{6)}$ 。

\section{2 工場のモデル化のための整理}

工場で実施される様々な生産活動は共通して, 製品状態 に変化を加える活動として考えることができる。これは, 購入された素材が“物の流れ”によってどの様に変化して いくかを捉え, その変化を加える主体が工場であり, 変化 を加えるという機能が，工場の基本機能であると認識する ものである。そこで本節では, 工場シミュレータの構成要 素を整理する。

3.2 .1 製品の状態に変化を加える基本単位

製品状態に変化を加える活動として造船工場における生 産活動を整理すると,以下のように整理することができる。

変換活動：製品に対して形態変化を加える活動。加工工 程, 組立工程, 搭載工程などで実施される生 産活動全般。

運搬活動：製品に対して位置変化を加える活動。機能別 に配置された様々な工場間を，生産対象であ る部品や中間製品を運搬する活動。

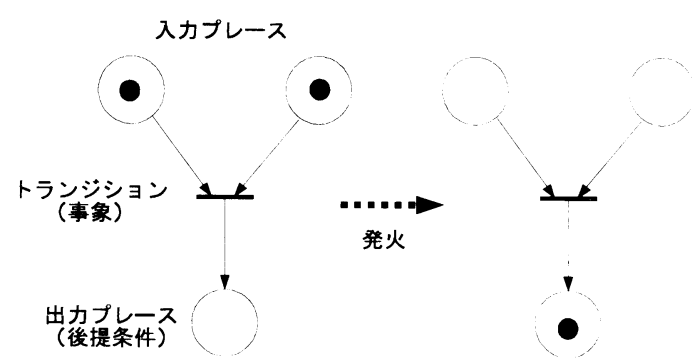

(A)トランジションは発火可能

(B)発火後のトークンの移動

Fig. 3 Petri Net (Place, Transition, Token, Arc) 
停滞活動：製品に対して時間変化を加える活動。工場の 処理能力を考慮し, 意図的に次工程の作業待 ちを作り出し, 全体的な生産効率を向上させ るための活動。特にこの活動は, 可能な限り 少ない方が望ましい。

上記の活動に対応する工場モデルの表現として以下に示 すような活動場所を定義する。この活動場所は，著者らの 既研究での工程資源に相当する7゙。

変換活動を実施する主体：作業所（定盤を有する加工・ 組立場所)

運搬活動を実施する主体：運搬設備（移動台車，クレー ンなど）を含む物理的空間

停滞活動を実施する主体：ストックヤード（部品や中間 製品を一時的に保管する場所）

\section{2 .2 工程資源を構成する作業資源}

前項で述べた構成要素には，その活動を実際に実施する 生産資源が存在する。例えば, 組立定盤などの作業所では, 溶接機やクレーン, 作業者などが存在する。本研究では, それらの生産資源を作業資源と呼ぶ。この作業資源に能力 因子による制約が記述される。また，個々の作業資源に生 産能力を記述することによって, 管理物量から作業に要す る時数などを算出することができる。この作業資源が工程 資源にどれほど存在するかは, 工程資源自体の処理能力に 密に関係する。

\section{3 ペトリネットによる基本的表現}

工場における生産活動を「変換活動」,「運搬活動」,「停 滞活動」の三つの活動に整理した。本研究では, それらの 活動を一般的に捉え，「製品状態に変化を加える活動」をぺ トリネットによって表現することを検討した。

3.3.1 生産活動における事象と状態の表現

本研究では, ペトリネットを利用して, 生産活動におけ る事象と, 事象間に存在する活動の状態を表現することを 検討した。「変換活動」,「運搬活動」,「停滞活動」の具体的 な表現は後述するが, 共通する表現を以下のように検討し た (Fig. 4)。

（1）トランジションによる事象の表現

製品状態を変化させる活動には, 必ず事象が存在する。 例えば, 変換活動においては組立作業を開始する事象, 組 立作業を終了する事象などである。運搬活動, 停滞活動に おいても同様に事象が存在する。ここで, 生産活動におけ る事象を整理すると,「活動を開始する事象」と「活動を終 了する事象」の二つの事象が認識できる。本研究では, 各々 の事象をトランジションを利用して表現する（Fig. 4 (a))。

（2）プレースによる状態の表現

上記 ( 1 )の事象は, 活動の状態を区分けするものである と理解できる。この二つの事象によって,「活動の開始を待 つ状態」,「活動を実施している状態」,「活動が終了した状
態」が発生する。本研究では, プレースを利用して, 事象 間に存在する活動の状態を表現する (Fig. 4(a))。

(3) 時間経過の表現

上記（1）（2）で示した表現によって，トランジションで 表現された各事象が発火することによって, 活動の状態を 表現するプレースにトークンが格納され，状態を表現する ことができる。また，トランジションに様々なプレースを アークで結線することによって, 事象を生起させる条件を 付加することができる（Fig. 4(b))。

生産活動のシミュレーションでは, 活動の時間経過を考 虑する必要がある。そこで本研究では, 活動の状態を表現 するプレースに時間をコントロールさせる機能を付加する ことができる「時間ペトリネット」を利用する。具体的に は,「活動の実施中」を表現するプレースは, 指定の時間が 経過するまで, トークンを保持し, 後続するトランジショ ンの発火要因として扱われないものとする。時間の指定方 法に関しては後述する。

\section{3 .2 生産対象と作業資源の表現}

本研究では, 生産活動の対象である生産対象, および主 体である作業者や生産設備などの作業資源をトークンとし て表現している。これらのトークンには, 生産対象や作業 資源の情報が記述され，それらの情報を直接利用すること によって活動に要する時間を算出することができる。各々 の表現を以下に示す。

\section{(1) 生産対象の表現}

生産対象をトークンとして表現することによって, 生産 活動における“物の流れ”を表現している。生産対象のト ークンには, 中間製品に関する製品モデルの情報が記述さ れる。このトークンは, 活動の状態を表現するプレースに 移動する。トークンの位置によって, 活動の状態を把握す ることができる。さらに，トークンがプレース間を移動す る履歴を収集することによって活動の実施履歴を獲得する

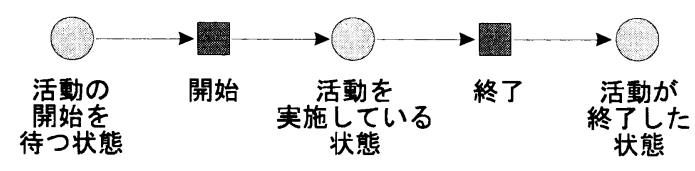

(a) 事象(活動)と状態の表現

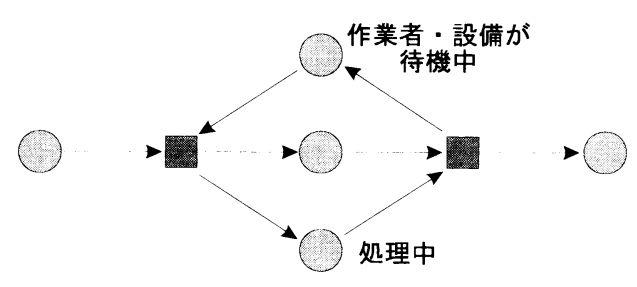

(b) 事象 (活動)を生起させる条件の付加

Fig. 4 Event, State, and Condition of Factory 
ことが可能となる。

（2）作業資源の表現

作業資源をトークンとして表現することによって，トラ ンジションで表現される事象が生起する条件として利用す ることができる。作業資源のトークンには, 作業者や生産 設備の情報が個々に記述される。また，「作業中」や「待機 中」などの作業状態を表現するプレースを用意することに よって，作業資源の作業状態を表現することができる。さ らに, プレースにトークンが存在する時間履歴を収集する ことによって, 作業者や生産資源の作業履歴を獲得するこ とが可能となる。

\section{4 ペトリネットによる生産活動の表現}

前節で述べた工場モデルのペトリネットによる基本的表 現を利用して, 具体的な生産活動を以下のように表現した

(Fig. 5)。

\section{4 .1 変換活動の表現}

生産対象の形態変化を加える活動である変換活動は，そ の活動を実施する作業所に生産対象が搬入されることによ つて活動を開始する前提が成立する。作業所間の“物の流 れ”は，作業所の「搬入」「搬出」のトランジションが発火 することによって表現される。「搬入」「搬出」のトランジ ションは, 他の活動と接続するための節点として利用され る。本研究では, 問題を簡略化するために, 作業所内では “物の流れ”は存在しないものと考えた。

「変換活動待ち」のプレースに格納されるトークンの時間 履歴から, 変換活動の停滞状況を把握することが可能であ る。システム内ではトランジションが発火し, プレースに あるトークンが変化することにより, 工場内で事象が生起

し，工場内の状態が変化する様子が表現される。 トランジション: 搬入, 活動開始, 活動終了, 搬出 プレース：活動の状態（変換活動待機中, 変換活動中,
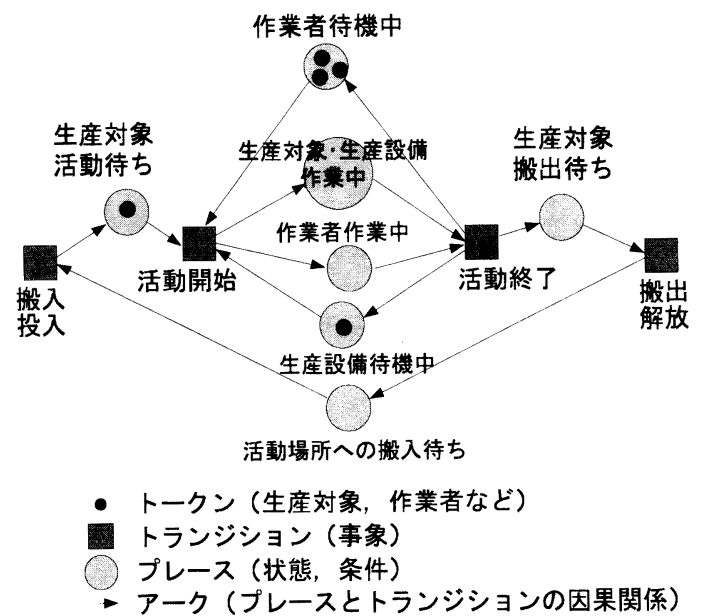

Fig. 5 Petri Net Simulation Model
搬出待機中）作業の状態（作業中，待機中） トークン：生産対象, 作業者や生産設備

\section{4 .2 運搬活動の表現}

作業所やストックヤードに対して生産対象を搬入した り，搬出したりする運搬活動は，運搬設備に生産対象が投 入されることによって活動を開始する前提が成立する。運 搬活動における事象と状態はトランジションとプレースに よって以下に示すように表現される。

トランジション: 投入, 運搬開始, 運搬完了, 解放

プレース：活動の状態（運搬待ち，運搬中，解放待ち） 作業の状態 (作業中, 待機中)

トークン：生産対象，作業者や運搬設備（クレーン，搬 送台車)

\section{4 .3 停滞活動の表現}

停滞活動は, 効率的な生産活動を実施するために, 意図 的に生産対象をストックヤードなどの保管場所に保管させ る活動として定義されている。停滞活動も, 変換活動や運 搬活動と同様に，場所という有限の資源を使って生産対象 に対して停滞という作業を実施する活動であり，変換活動 や運搬活動と同様のペトリネットで表現される。

トランジション: 投入, 停滞開始, 停滞完了, 解放 プレース：活動の状態（停滞待ち，停滞中，搬出待ち） トークン：生産対象

\section{4 .4 作業時間の算出}

変換活動と運搬活動の表現では，「活動中」の状態を表現 するプレースに時間をコントロールする機能を付加してい る。時間は, 次のように算出している。

1）変換活動：トークンに記述されている生産対象の情 報から得られる管理物量と，作業を実施する作業者 や生産設備の生産能力によって算出される。

2）運搬活動：運搬する経路の情報として運搬する作業 所間の距離, 生産対象のトークンに記述されている 情報から得られる重量や大きさなど，および作業を 実施する運搬設備の運搬能力から算出される。

また，停滞活動の表現では，プレースに時間をコントロ ールする機能は付加されず，停滞状態の製品が必要とされ る状態に遷移するまでの時間が停滞活動の時間として算出 される。

\section{5 ペトリネットの階層表現}

ペトリネットの階層構造を利用することによって, 前節 で述べた活動を表現するぺトリネットは一つのプレースに 集約することができる（Fig. 6)。集約されたプレース間は 「搬入」や「搬出」などの事象を生起するトランジションに よって結ばれる。このように階層的に表現されたぺトリネ ットは，上位階層は工場における“物の流れ”を表現する ものであり，下位階層は”“作業の流れ””を表現するもの であると考えられる。 


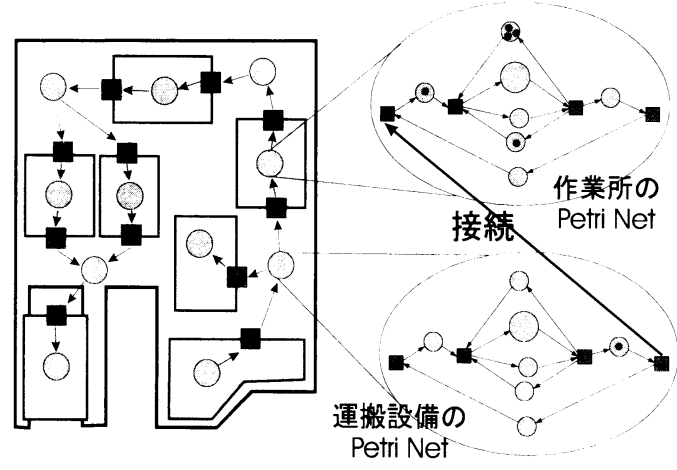

Fig. 6 Hierarchy of Petri Net Simulation Model

\section{4. シミュレーションに必要な情報}

造船工場には, 固定化された生産ラインは存在しないが, 個々の製品の組立経路は計画される。この組立経路は, “物 の流れ”の道筋を確定するものである。本研究では, 表現 された工場モデルによって生産活動をシミュレーションす るための情報として以下の情報を準備する。

a）生産対象の情報

b）生産対象毎化設定される組立経路（生産ルート）

c）生産資源の処理順序

以上の情報の a）とb)は, 著者らが構築している工程計 画支援システムを利用することによって生成される情報で ある。本章では, これらの情報生成の流れを整理する。

\section{1 生産対象の抽出と組立順序の選定}

造船工場における生産対象として船またはそれを組み立 てる際の中間製品が挙げられる。著者らが研究開発してい る SODAS (System Of Design and Assembling for Shipbuilding）には，工場内を流れる中間製品を表現する製品モ デルとして組立モジュールが定義されている。また, 作業 内容に関する情報を一括に管理する作業モデルを定義して いる。

（1）中間製品（組立モジュール）の抽出

組立モジュールは, 完成品として定義された船をカット 機能によってブロック分割することで任意に抽出すること ができる。組立モジュールは，生産活動において「状態の 変化を加える対象」として認識される。組立モジュールが 管理する部材情報などから, 中間製品の総重量, 全接合線 に関する管理物量を容易に集計することができる。この管 理物量と使用する生産資源の処理能力とから必要工数や必 要時数などを容易に算出することができる。

（2）中間製品の組立順序の選定

ブロック建造法では，ある組立工程には先行する組立工 程が存在する。例えば搭載工程には先行する大組工程が存 在する。したがって，ある組立工程での中間製品は先行す
る組立工程で複数の中間製品を組み立てることで造られ る。先行する組立工程の中間製品と後続する工程の中間製 品の組立関係を考慮すると，すべての中間製品の組立順序 を取り出すことができる（Fig. 7(a))。ブロック分割によ つて抽出される複数の組立モジュールの組立順序を選定す ると, Fig. 7(b)に示すような作業モデルのグラフ構造が 生成される。図中の各ノードは作業モデルを表現し, 作業 の対象である組立モジュールが記述される。

\section{2 組立経路（生産ルート）の決定}

生産計画者は, 工程計画において以下に示すような計画 情報を選定し, 生産対象である中間製品の組立経路を決定 する。
a）組み立てる作業所の選定
b）運搬経路の選定
c）（必要ならば）中間製品の保管場所の選定

工程計画において決められる各種情報の生成方法や, 作 業モデルに管理される情報を整理する。

（1）生産資源の選定

抽出された中間製品をどの作業所（工程資源）で建造す るかを選定する際には，生産資源による能力因子の制約を 考慮する必要がある。指定された作業所に記述されている 能力と, 生産対象の中間製品から得られる管理物量を利用 して判定する。判定の結果, 制約に対して違反している場 合は, 別の作業所を選択する。このように建造する作業所 が選択されると，建造する中間製品を管理する作業モデル に選択された作業所が記述される。

\section{(2) 運搬経路の選定}

先行する組立工程のブロックを建造する組立作業の作業 モデルは既に生成されている。したがってこの組立作業を 実施する作業所をその作業モデルに記述することによっ て, 作業所間の前後関係が関係付けられる。ある組立作業 と先行する組立作業が異なる作業所で行なわれる場合，作 業所間の中間製品の運般を考える必要がある。運搬作業の 作業モデルを生成し，組立作業の作業モデル間に挿入する (Fig. 7 ( c ))。運搬作業を実施する運搬設備は, 運搬作業の 作業モデルに記述される。

\section{（3）保管場所の選定}

意図的に中間製品をストックヤードなどに保管したい場 合は, 運搬作業の挿入と同様に, 保管作業の作業モデルを 任意の作業モデル間に生成する (Fig. 7 ( c ) )。この生成さ れた作業モデルに選択された保管場所を記述する。

以上のように, 中間製品の組立順序を検討する際に生成 される作業モデルを利用して, 運搬経路, 保管場所の選定 などで生成された作業モデルが新たに生成され，すべて作 業モデルのグラフ構造として表現される。また, 選択され た工程資源は作業モデルに記述され，作業モデルと工程資 源の関係が生成される。この関係の生成によって, 各作業 はその作業が実施される場所として工程資源を参照し, 工 


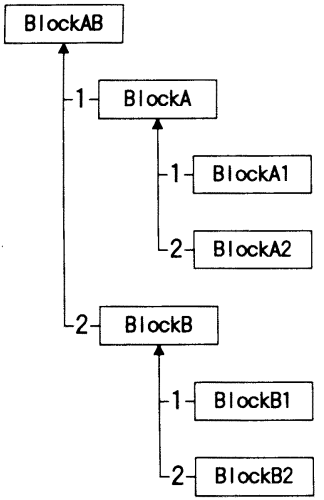

（a）ブロックの組立順序

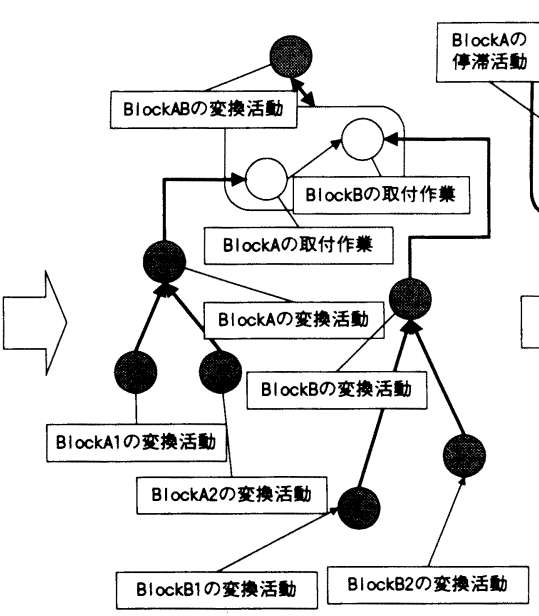

(b) 作業モデルの生成

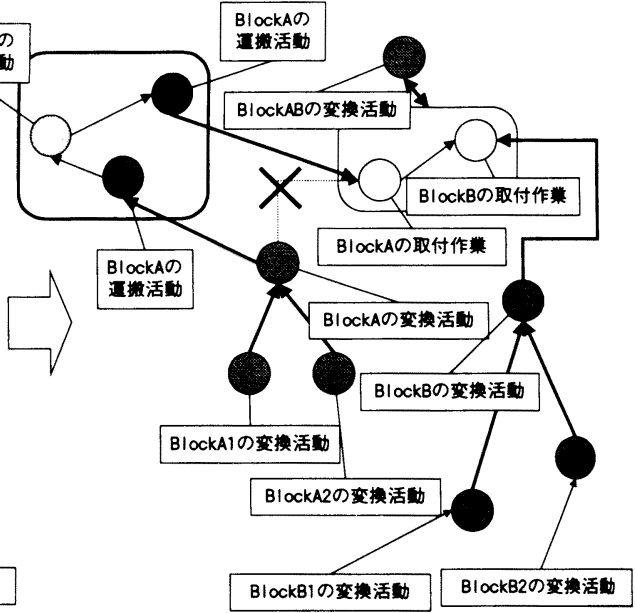

(c)組立経路を考虑した 作業モデルの生成

Fig. 7 Generation of Operation Model

程資源は実施すべき作業を参照することが可能となる。ま た，中間製品は作業モデルを介して，生産ルートの情報を 得ることが可能である。

\section{3 工程資源（作業所，運搬装置）の処理順序}

各工程資源で滞りなく変換活動を実施するためには, 各 工程資源に抢ける中間製品の搬入・搬出の順序を計画し, 処理順序を選定することが重要となる。

工程計画によって生成される組立順序は，一隻の船を構 成する全ての中間製品に対して相対的な順序となる。した がって,ブロック A をブロック A 1 とブロック A 2 から組 み立てるとき，作業所に搬入すべき順序は工程計画で求め られた組立順序となる。しかし，複数船を同時期に建造す ることを考えると，相対的な順序を決めることは困難な問 題となる。例えば，別船のブロック B の組立作業を考える とき，B の組立順序と上記ブロック A の組立順序には関係 は存在しなく, 計画者が優先度などを考慮して, 作業所に 搬入する順序を決定する必要がある。ある作業所の物の搬 入順序は, 先行, 後続関係にある作業所の変換活動に影響 を及ぼすため，工程計画では決定されない組立順序は工場 全体のスケジュールを考慮して決定する必要がある。

本研究では，以上の工程計画だけでは決定が困難な工程 におけるブロックの組立順序の検討を支援する逆方向のシ ミュレーションを提案している。

\section{4 逆方向のシミュレーション機能}

逆方向のシミュレーションは, 完成品である船から始ま り，最終的な部品である板部材まで製品を分解しながら工 場内を搭載工程, 大組工程, 小組工程へと, 逆方向に流し ていくものであり, 現実の生産活動とは逆方向の仮想的な シミュレーションである。
このシミュレーションを実行するシミュレータは, 本研 究で構築している工場シミュレータを応用して実現してい る。具体的には，ペトリネットによって表現される工場モ デルのペトリネットのトランジションとプレースを関係付 けるアークの方向を逆方向に設定することによって実現す るものである。

このシミュレーションの特徴は“物の流れ”が分散の方 向に進むために，各作業を行なう際に相手ブロックの待ち を考えなくてもよいという点である。このためにシミュレ ーションが途中で進行不可能（デッドロック）にならない ことが保証される。逆方向シミュレーションを行ない, こ こで得られた作業順序を反対に並べ直すことにより，工程 計画では得ることのできなかった異なるブロックに関する 組立作業間の順序を得ることができ, 組立作業のディスパ ッチングとして利用することができる。

\section{5. シミュレーションで獲得される情報}

本研究で構築した工場シミュレータを実行することによ って獲得される情報を整理する。

\section{1 “物の流れ”の可視化}

3 章で述べたように, 工場シミュレータはペトリネット を利用して構築されているので，ペトリネットの動的な性 質によってシミュレーション実行中に工場における生産活 動の“物の流れ”を視覚的に確認することができる。

本シミュレータでは二つのウインドウを用い, ペトリネ ットで階層的に表現された作業所内の “作業の流れ”と作 業所間の“物の流れ”を同時に確認できる。さらにシミュ レーションの実行後に, シミュレーション結果を利用して レイアウト表示された工場に, 中間製品が流れる様子がア 
ニメーション表示される。アニメーション表示される中間 製品は作業状態によって色分け表示され，任意の時刻にお ける中間製品の場所, 状態を確認することができる。

\section{2 生産情報の獾得}

シミュレーションの実行結果を集計することによって， より良いスケジューリングを立案するための情報として下 記に示す様々な情報を獲得することができる。

(1) 作業所での組立順序の提案

逆シミュレーションを実行することによって, 各作業所 での組立順序案が示される。これによって, 複数船も対象 にできるスケジューリングが可能となる。

（2）作業開始時間の決定

各作業に対して時間因子による制約を満たすスケジュー ルを生成することができ, 実行可能な作業開始時刻・作業 終了時刻が得られる。

(3) 停滞状態の抽出

作業所や運搬装置などに中間製品が割り当てられている 状態を考えると, その中間製品に対して常に作業が実施さ れているわけではなく，作業が実施されていない状態があ る。このような作業が実施されていない状態を ‘活動の停 滞状態”と呼ぶことにする。活動の停滞状態’には,「変換 活動の停滞状態」,「運搬活動の停滞状態」などが考えられ る。本シミュレータではこれらの゙活動の停滞状態'を以下 のように分類した。

変換活動の停滞状態：作業者の空き待ち, 設備の空き待 ち，相手ブロック待ちなどによって発生する 停滞状態

運搬活動の停滞状態：運搬設備の空き待ち，次作業所の 空き待ちなどによって発生する停滞状態

以上のように活動の停滞状態をシミュレーション結果から 抽出することによって，何が原因で“物の流れ”に滞りが 生じているかを知ることができる。

さらに，工程資源が管理するスケジュール情報を活用す ると各ブロックの作業所占有時間に対する実際の作業時間 と作業待ち時間の割合をグラフ表示できる（Fig. 8)。
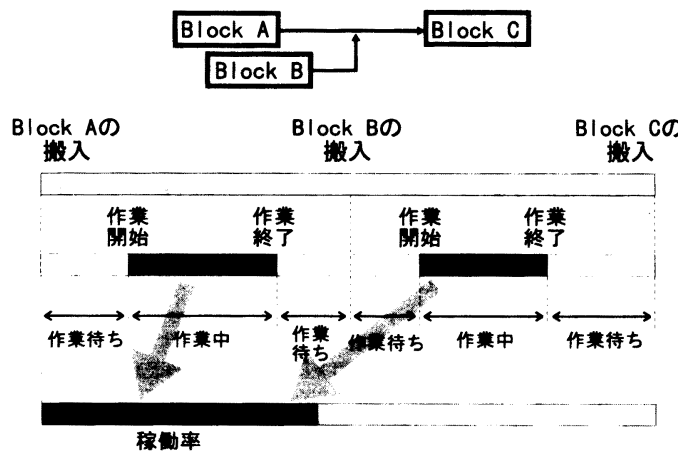

Fig. 8 Stagnation in Flow of Jobs

\section{6. シミュレーションを支援する機能}

作業所，設備，作業者などの割り当てや製品の組立順序 などの組み合わせを検討して最適なスケジュールを求める ことは非常に困難である。本研究では最適化の検討を支援 するために, 計画の前提となる様々な条件を容易に変更し, 試行錯誤的に良好なスケジュールを立案することができる 機能を定義した。

本シミュレータでは, シミュレーションの実行に必要な 様々な情報の変更, シミュレーションの再実行, ガントチ ヤートや山積みチャートによる結果の分析を繰り返し実行 しながら, 製品情報, 工場情報, 計画情報のより良い組み 合わせを検討することを支援している。以下に本シミュレ ータの機能を整理する。

\section{1 計画情報の変更機能}

得られたスケジュールを変更することによって“物の流 れ”や“作業の流れ”の滞りを解消し，スケジュールを改 善することができる。本システムにおける計画変更機能を 以下に挙げる。

(1) 作業所での組立順序の変更機能

作業所で処理すべき複数の中間製品の組立順序を変更す る。先に述べたように，中間製品の建造の優先順序を変更 することによって, 工場への搬入・搬出順序も変更され, 工場全体のスケジュールが大幅に修正される可能性があ る。

（2）組立経路の変更機能

中間製品を違う生産環境に割り当て直すことによって中 間製品の組立経路を変更し, “物の流れ”を変更する。

\section{2 工場モデルの変更機能}

本シミュレータでは，工場モデルを任意に設計すること ができる工場設計機能が定義されている。この機能を利用 すると工場モデルの自由な変更, 追加や削除等も可能であ る。工場モデルを変更し, シミュレーションを再実行させ ることにより生産環境の変化がスケジュールに与える影響 を確認することができる。また, 後述するように設備の故 障などにも対応できる。本シミュレー夕における工場モデ ルの変更機能を以下に挙げる。

（1）作業者, 作業設備の変更

作業者, 設備の数や能力を変更する等, 主に変換活動に 影響を与える変更である。

（2）工場レイアウトの変更

作業所の数を増やす, 配置を変える, 停滞場所を広くす る等, 主に運搬活動に影響を与える変更である。

\section{3 製品モデルの変更機能}

工場内を流れる物を直接変更することによって，その物 を生産するスケジュールは変更される。このような物の変 更は製品モデルをべースとした設計支援システムと統合化 されることによって容易に実現可能である。以下に変更機 
能を分類し整理する。

（1）ブロック分割の変更機能

ブロック分割の仕方や，得られたブロックの組立順序を 変更する。当然, 割り当てられる生産資源や生産ルートな どの変更も伴う。流れる物自体の変更である。

(2) 船体構造の変更機能

上記（1）の変更に加えて，ブロック分割だけでなく船体 構造自体を変更する。製品モデルをベースとした設計支援 システムと統合化されているので，製品モデルの変更は設 計変更機能を利用することによって容易に実現できる。

\section{4 シミュレーションの部分的実行機能}

生産活動の途中に発生する作業遅れや, 設備の故障, 天 候などの外乱によってある時点からの計画変更を余儀なく される場合，スケジュールのすばやい変更の必要性が生じ る。この時, 様々な条件が存在するために, ある条件の変 更が他のスケジュールに与える影響を短時間に知ることは 非常に困難である。本研究のシミュレータは, 任意の時間 以降のシミュレーションを部分的に行うことができるの で, 様々な変更よって生じる影響を容易に短時間で把握す ることができる。

\section{7. 工場シミュレータの実行例}

本章では，実際に構築したシミュレータに実装した工場 モデルの概略仕様と, シミュレーションの実行手順, およ びシミュレーションの実行例を示す。なお，本シミュレー 夕は著者らが研究・開発している SODAS 上に, オブジエ クト指向言語である Smalltalk を用いて構築されている。

\section{1 工場モデルの設計}

本研究で定義した工場モデルはグラフィック・ユーザ・ インタフェースによって自由に設計することが可能であ る。先ず, 工場全体のレイアウトから設計し, ドック, 組 立定盤，ストックヤードなどが設計される。さらに運搬装 置なども自由に配置することができる。設計される工場の 工程資源は, 設計と配置の時点で, 自動的に工程資源を表 現するペトリネットが生成される。工程資源間の接続を考 慮することによって，個々のペトリネットが接続されるこ とになる（Fig. 9）。

設計した作業所, 運搬装置, ストックヤードに対して生 産能力を記述する。管理物量から作業時間を算出するため に必要な情報や, 能力因子の制約に関係する設備制約の情 報を記述する。これらの情報は, 何時でも変更することが 可能である。設備能力を記述する際に, 特に作業所では溶 接作業者や溶接機などの台数などを記述する。また, 作業 所やストックヤード間の空間的な位置関係は直接設計情報 から算出され, 運搬作業に要する時間算出の情報として利 用される。運搬経路も任意に指定できる。

\section{2 工程計画の立案（シミュレーションの前準備）}

本シミュレータは工程計画を実施してから実行される。

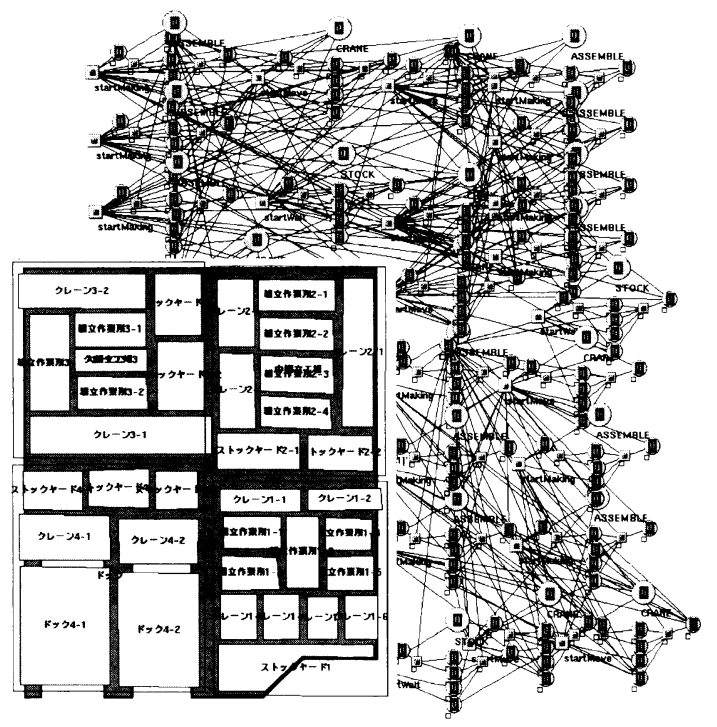

Fig. 9 Petri Nets for Simulation of Ship Yard

工程計画の手順は以下に示すものである。

1）設計支援システムで船体構造の製品モデルを生成 し，ブロック分割を実行する。

2）ブロック分割によって, 搭載ブロックから部品まで 抽出する。

3）搭載ブロックなどの中間製品，および部品は共通に 組立モジュールとして管理される。

4）生産計画者は, 生産計画支援システムを用いて組立 順序，組立場所を選定する。

5）組立に要する溶接機の種類・台数, 溶接作業者の人 数などの情報を入力する。

6）入力や生成された作業情報を管理する作業モデルを 表現する作業オブジェクトが生成される。作業オブ ジェクトには生産対象，工程資源情報などの情報が 記述され管理される。

7）作業オブジェクトはノードとして定義されており, 前後関係にある作業オブジェクトと有向リンクで接 続されている。

\section{3 シミュレーションの実行手順と実行例}

本研究で構築したシミュレータを用いてシミュレーショ ンを行なう実行例を以下に示す。Fig. 9 のように定義され た工場を使用する。

(1) 設計から工程計画

生産対象となる船を Fig. 10 のようにブロック分割し, 工程計画を立案する。

（2）日程情報の生成

作業オブジェクトに記述されている生産資源の情報と, 生産対象の情報から得られる管理物量とから作業に要する 時間が算出される。算出された作業時間は作業オブジェク 


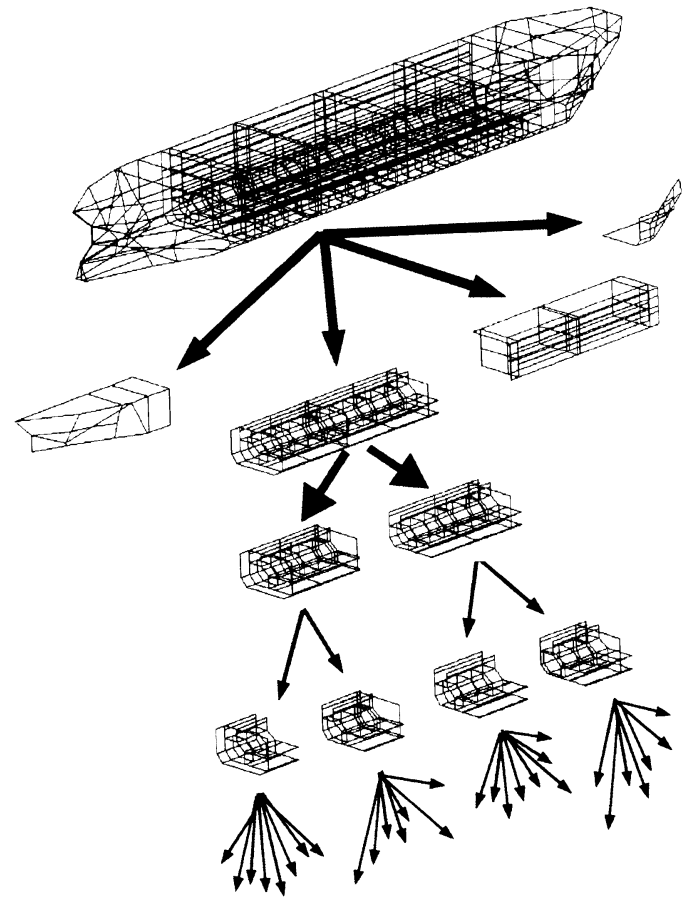

Fig. 10 Dividing Blocks for Simulation
トに管理される。したがって，ペトリネットを利用しない で, 工程計画で得られた作業情報を利用し，作業を時間軸 に展開することによって日程情報が獲得される。

Fig. 11 に示される日程情報は, 生産資源の時間要因によ る制約は全く考慮されておらず，作業の前後関係を重視し た日程情報の生成となっている。したがって一つの設備が 同時刻に複数の作業を実施するといった日程が生成されて

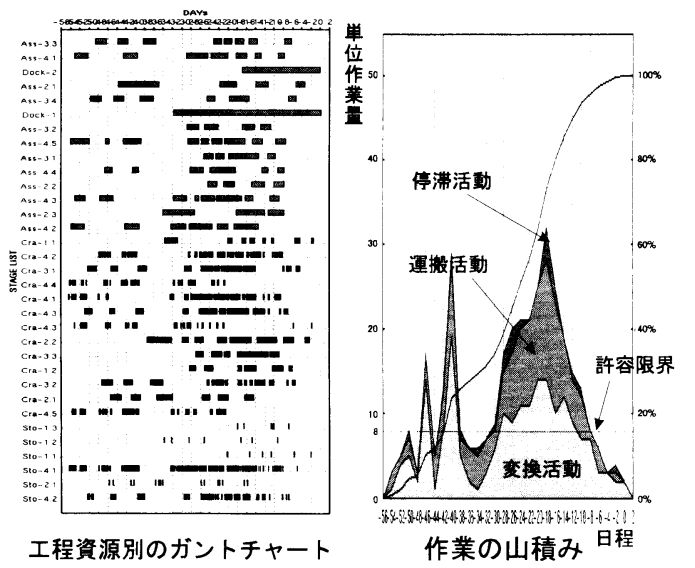

Fig. 11 Schedule Data with No Restrictions

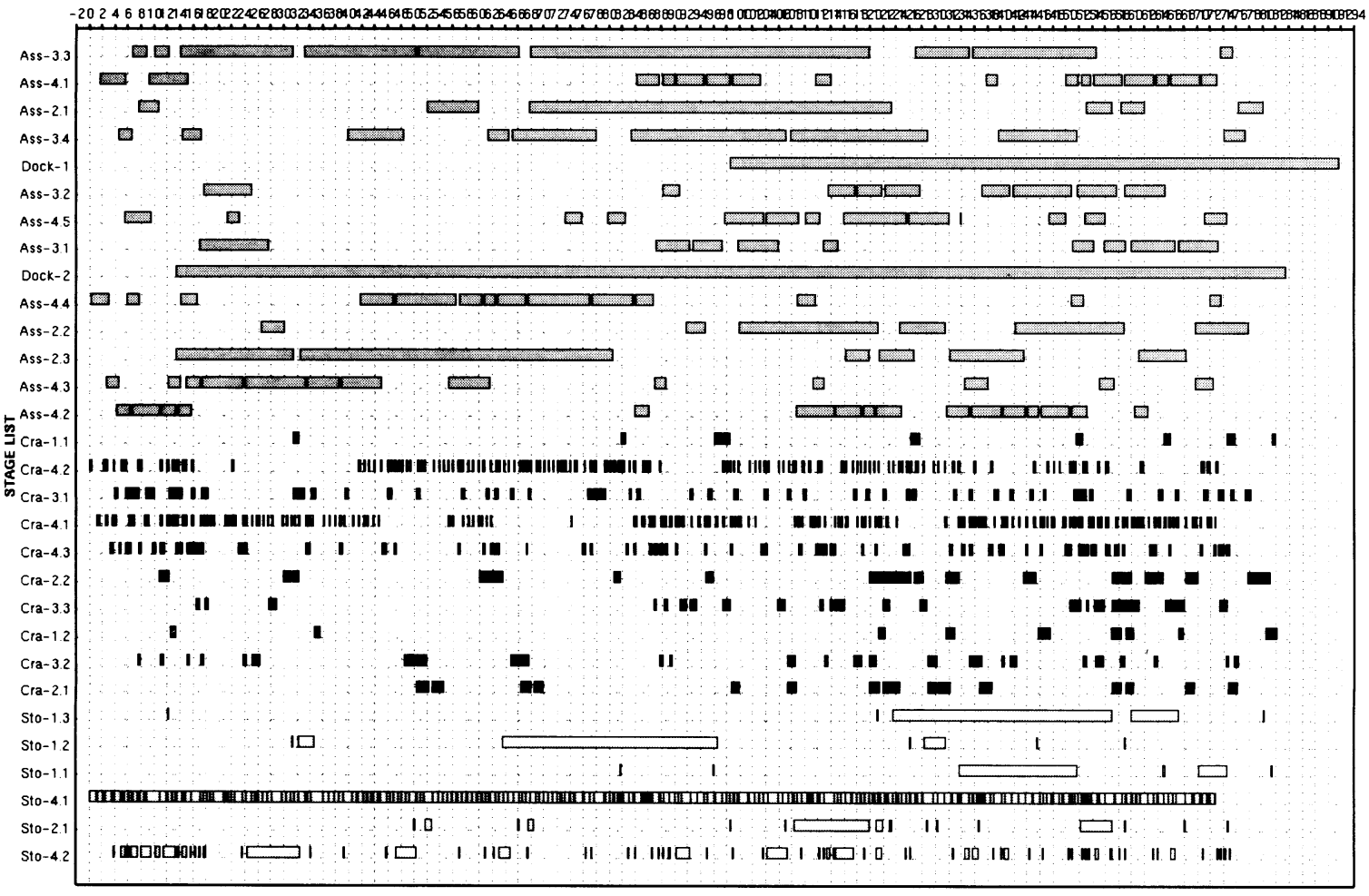

Fig. 12 Schedule Data for Job Stages, Cranes, and Stock Yards 
いる。またそれに伴い, 作業の山積みを見てみると, 極め て多い作業が実施される日程であることが理解できる。以 上の日程情報は, 著者らが既に構築している日程計画支援 システムによって生成される。

( 3 ） シミュレーションの実行

本研究で構築されたシミュレータによってシミュレーシ

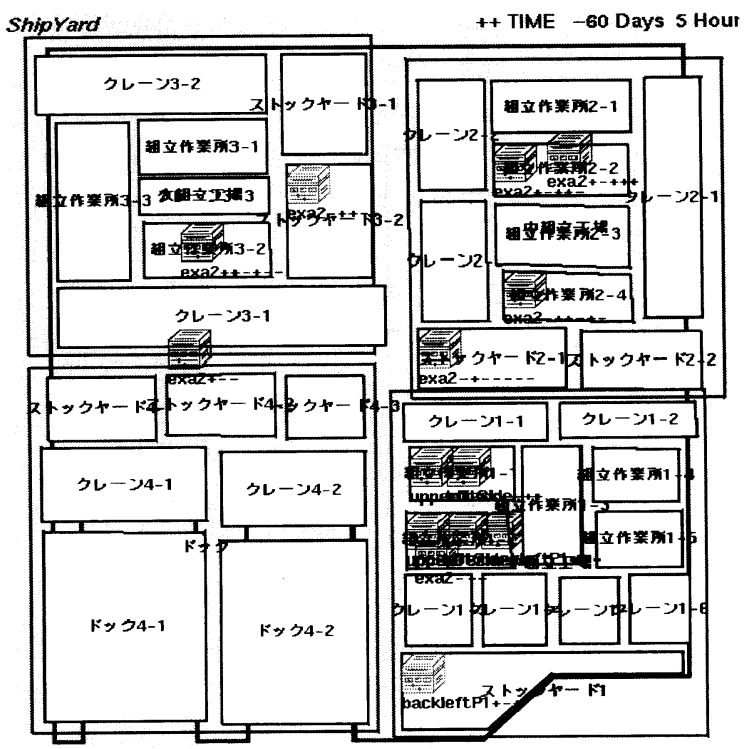

Fig. 13 Graphical View for Simulation (Flow of Products)
ヨンを実行すると, Fig. 12 に示すような日程情報が生成さ れる。この日程情報は，「時間因子の制約」を考慮したもの となって抢り，生産資源は同時刻に複数の作業を実行しな いスケジュールが生成されている。

また, Fig. 13 に示すように工場内の物の流れがアニメー ション表示され, 視覚的に物の流れが悪い工程を確認でき, 立案された日程情報の問題点を容易に把握することができ る。

\section{4 計画の修正とシミュレーションの再実行}

本システムは，最適な日程情報を自動的に提示するシス テムではない。したがって，計画者は，システムが表示す る様々な情報を判断し, 計画の修正を実施する必要がある。

前節のシミュレーション結果として得られる生産資源の 使用率などの情報から，どの生産資源が隘路となっている かを判断し，変更機能を利用してシミュレーション条件を 変更し，再実行した例を簡単に示す。

前節の計画は，大組立の作業所で必要となる全てのブロ ックを，その前工程となる一箇所の作業所で建造すること を計画したことがシミュレーションによって確認できた。 そこで，作業能力に余裕のある他の作業所を有効に利用す るために，下記のように計画を修正し，シミュレーション を再度実施した。

\section{1）工場設備の変更}

材料ストックヤードから小組工程の作業所の経路上にあ る運搬設備を 2 基から 5 基に増加し, 運搬する中間製品を 割り振り直す。

2）作業所のガントチャートや作業所の作業効率図を参
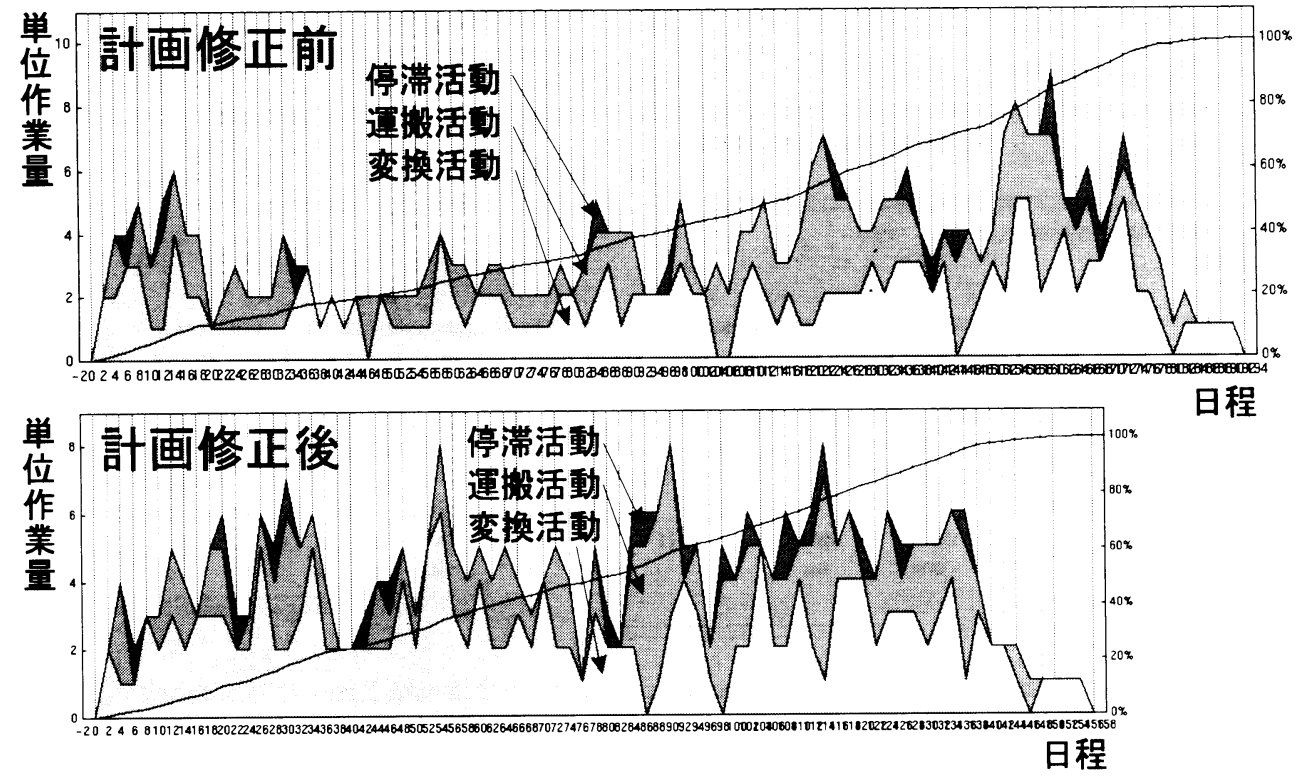

日程

Fig. 14 Difference of Simulation Results (Load Chart) 
考にし，作業が実施されていない作業所が多い時間带を見 つけ，作業所の作業を割り振り直す。

以上のように計画を修正することによって, Fig. 14 に示 される作業の山積みグラフから，作業が平準化されている ことが理解できる。また，運搬装置の増強により，作業所 へのブロックの搬入や搬出がスムースに実施され，作業所 の稼働率が上昇したことが Fig. 15 のグラフから読み取る ことが可能である。

以上のように，本システムでの計画の修正は，工場の変 更も含めて，様々な条件の組み合わせを検討し，より効率 の良い計画情報を生成することを支援している。

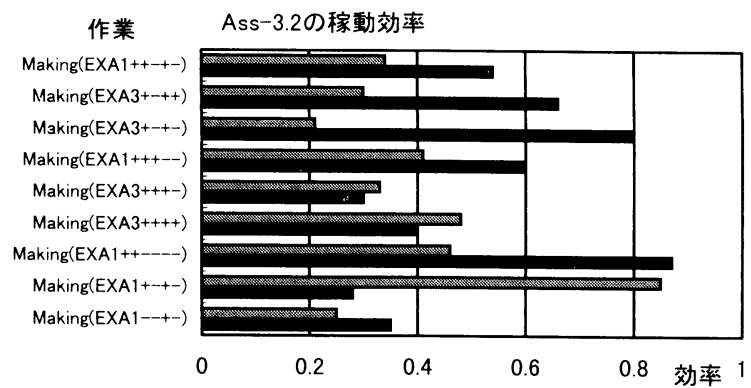

作業

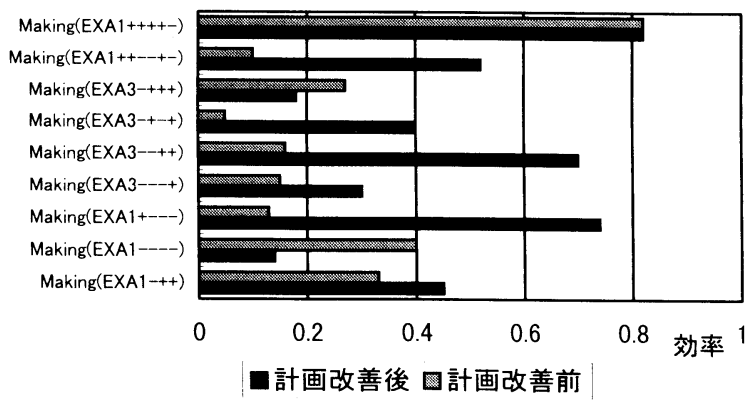

Fig. 15 Difference of Simulation Results (Operation Ratio)

\section{8. 結論}

本研究によって得られた知見を以下に示す。

（1）造船工場の持つ機能を整理し，ペトリネットを利 用してモデル化し，造船工場シミュレータを構築 した。

（2）工場シミュレータを構築するためには十分に工場 をモデル化する必要があり，工場の変換機能に着
目し生産資源を整理した。

（3）生産資源の制約として，能力因子による制約，時 間因子による制約を整理した。時間因子の制約を 表現するモデルとしてペトリネットが有効である ことを確認した。

（4）整理した生産資源に基づき，生産資源の能力の記 述方法を検討し，工程計画における能力因子の制 約を考慮することができる情報処理方法を検討す ることができた。

（5）工場の生産活動をシミュレーションするために必 要な生産情報を整理した。さらに，構築されたシ ミュレータを用いてシミュレーションを行い，そ れにより得られる情報も整理した。

（6）最適な生産計画を得るためには，製品モデルの変 更，工程計画の変更，工場モデルの変更などを考 慮する必要があり，それらのモデルが十分に統合 化されている必要性を確認することができた。

以上によって最適化の困難なスケジューリングにおける シミュレーションの有効性を示すことができた。

\section{謝辞}

本論文を作成するにあたり, 東京大学工学部船舶海洋工 学科野本研究室の猪上太氏からは多大な協力を頂きまし た。厚く御礼を申し上げます。また, 本研究は科学研究費 (基盤研究 $(\mathrm{A})$ ) の援助を受けていることを付記し, 深謝致 します。

\section{参 考 文 献}

1）人見勝人, 生産システム工学, 共立出版, 1990

2）佐々木文夫，日程計画抢よび工程管理システム，造 船におけるシステム技術第 16 章, 日本造船学会シ ステム技術委員会第 I 部会編, pp. 157-168（1984）

3）峰村隆久, 造船業 CIM のための日程計画情報の表 現に関する研究, 日本造船学会論文集第 174 号, pp. 673-681 (1993)

4）青山幹雄・内山直志・平石邦彦：ペトリネットの理 論と実践, システム制御情報ライブラリ一朝倉書店 (1995)

5) James L. Peterson・市川惊信訳：ペトリネット入 門, 共立出版 (1984)

6）吉川健・孫昌秀・赤根和己：Smalltalk-80による生 産システムシミュレータ, 第 2 回 Smalltalk シンポ ジウム論文集, pp. 223-230（1991）

7）青山和浩, 製品モデルをべースとした生産計画のモ デル化に関する研究, 日本造船学会論文集第 176 号, pp. 563-574 (1994) 